\title{
Does the status quo have to remain? The current legal issues of transsexualism in Poland
}

\author{
Paweł Bartnik ${ }^{1, A-F}$, Joanna Kacperczyk-Bartnik ${ }^{1, A-F}$, Maciej Próchnicki ${ }^{2, A-F}$, \\ Agnieszka Dobrowolska-Red0 ${ }^{1, D-F}$, Ewa Romejko-Wolniewicz ${ }^{1,0-F}$ \\ ${ }^{1} 2^{\text {nd }}$ Department of Obstetrics and Gynecology, Medical University of Warsaw, Poland \\ ${ }^{2}$ Department of Legal Theory, Jagiellonian University, Kraków, Poland \\ A - research concept and design; $\mathrm{B}$ - collection and/or assembly of data; $\mathrm{C}$ - data analysis and interpretation; \\ $D$ - writing the article; $E$ - critical revision of the article; $F$ - final approval of the article
}

Address for correspondence

Maciej Próchnicki

E-mail: maciej.prochnicki@uj.edu.pl

Funding sources

None declared

Conflict of interest

None declared

Received on May 4, 2019

Reviewed on September 23, 2019

Accepted on December 13, 2019

Published online on March 31, 2020

Cite as

Bartnik P, Kacperczyk-Bartnik J, Próchnicki M, DobrowolskaRedo A, Romejko-Wolniewicz E. Does the status quo have to remain? The current legal issues of transsexualism in Poland. Adv Clin Exp Med. 2020;29(3):409-417. doi:10.17219/acem/115294

DOI

10.17219/acem/115294

\section{Copyright}

Copyright by Author(s)

This is an article distributed under the terms of the

Creative Commons Attribution 3.0 Unported (CC BY 3.0)

(https://creativecommons.org/licenses/by/3.0/)

\begin{abstract}
Transsexual persons often undergo the process of transition, which is a long, multi-stage procedure. One of the stages, often final, is the lawful reassignment of sex, which is often perceived by transsexual individuals as more meaningful than the medical interventions. The aim of the study was to analyze the current legal situation of transsexual individuals in Poland. An in-depth review of legal documents and their association with current medical knowledge on transsexualism together with a presentation of solutions established worldwide were performed. Analyzed aspects include surgical interventions, sex assignment and correction of birth certificate. The current legal situation of lawful sex reassignment in Poland is complex and far from friendly towards transsexual people. Recent attempts to improve the situation were unsuccessful and current strategies to help transsexual people seem to be ineffective. Apart from the medico-legal problems, a number of issues connected with transgenderism depend on the socio-political views. The most notable drawback of the currently binding judicial procedure of legal sex change is the requirement of suing parents, spouse and children. This could be avoided if the change was performed in a non-litigious mode of proceedings, in which the medical criteria of the World Health Organization (WHO) and an opinion of a strictly regulated team of experts were central factors.
\end{abstract}

Key words: patient advocacy, sex reassignment procedures, transsexualism 


\section{Introduction}

The commonly used umbrella term 'transgender' (as well as 'transsexual' or 'gender incongruent') addresses the situation in which the psychological gender identity of an individual differs from the gender established by the external sexual anatomy at birth. This article will focus strictly on the case of transsexualism, in which a person identifies with another gender and wants to undergo a transition, i.e., the process of aligning the desired gender. We do not analyze the issue of genderqueer persons, whose sexual identification is neither masculine nor feminine, or of those transgender individuals who neither seek medical help nor have a desire to undergo the transition process. The World Health Organization (WHO) ICD-10 Classification of Mental and Behavioural Disorders currently classifies this problem under the code F64.0. ${ }^{1}$ The direct cause of transsexualism remains unknown; however, numerous genetic and perinatal hormonal factors are suspected to be involved. ${ }^{2}$ The psychological experience of transsexualism, which is referred to as gender dysphoria, leads to chronic suffering. Transsexual persons are referred to according to their perceived/desired gender. Women in the bodies of men, i.e., persons who desire to live as women, are referred to as male-to-female (MTF) transsexuals. People in the opposite situation are called female-to-male (FTM).

The prevalence of gender incongruence varies, depending on the population and study method. The prevalence of clinically established transsexualism varies from $0.7 / 100,000$ in Iran to $100 / 100,000$ in Iceland, with a mean value of 9.2/100,000. ${ }^{3-5}$ However, a meta-analysis of studies about transsexualism epidemiology, which were based on self-reported transgender identity, revealed a much higher transgender occurrence of 355/100,000. ${ }^{4}$ Therefore, it may be suspected that gender incongruence is highly underdiagnosed. Most of the studies report a higher number of MTF transsexuals than of FTM. ${ }^{4}$

The process of diagnosing transsexuality is long and complicated. The gender identity has to exist for at least 2 years and no chromosomal anomalies should be present. ${ }^{2}$ In addition, the identified problem should not be a result of any confounding psychiatric comorbidity (e.g., schizophrenia). ${ }^{3}$ The full diagnostic process is most commonly performed in patients who want to undergo the gender transition process.

The diagnostic criteria of transgenderism are likely to be modified soon. On June 18, 2018, during the preparation of this article, the WHO announced the new ICD-11 classification on their website. ${ }^{6}$ The new code is HA60 and the new name for the diagnosis is 'gender incongruence of adolescence or adulthood'. The new criteria read as follows: Gender incongruence of adolescence and adulthood is characterized by a marked and persistent incongruence between an individual's experienced gender and the assigned sex, as manifested by at least 2 of the following: 1) a strong dislike or discomfort with the one's primary or secondary sex characteristics (in adolescents, anticipated secondary sex characteristics) due to their incongruity with the experienced gender; 2) a strong desire to be rid of some or all of one's primary and/or secondary sex characteristics (in adolescents, anticipated secondary sex characteristics) due to their incongruity with the experienced gender; 3 ) a strong desire to have the primary and/ or secondary sex characteristics of the experienced gender. The individual experiences a strong desire to be treated (to live and be accepted) as a person of the experienced gender. The experienced gender incongruence must have been continuously present for at least several months. The diagnosis cannot be assigned prior to the onset of puberty. Gender variant behavior and preferences alone are not a basis for assigning the diagnosis. As can be seen, much emphasis is put on the willingness to change the sex characteristics. This is similar in many aspects to the definition proposed by the DSM-V classification. ${ }^{7}$ The official publication date of the new classification is scheduled for May 2019 and the implementation of the new classification by the associated countries is planned for 2022 .

Transsexual individuals, in addition to the suffering caused by gender dysphoria, have to deal with social stigma. ${ }^{8}$ The severity of social stigma differs depending on the tolerance level of the particular society, the legal status of transsexualism and the physical gender of the transgender individual.

The transition process is a complex procedure wherein the phenotype of an individual is transformed in order to match the gender identity. Currently, there is no method to change psychological identity and, therefore, transition remains the most effective method to reduce gender dysphoria in transsexual individuals. ${ }^{9}$ In transgender men, this includes androgen hormonal therapy and an optional twostage surgical therapy, including bilateral mastectomy and hysterectomy with male genital reconstruction. ${ }^{9}$ The $2^{\text {nd }}$ stage of the surgery is often not performed, as it is not desired by the patients because of unsatisfactory surgical results. In transsexual women, the transition includes hormonal therapy, which focuses on androgen suppression and estrogen supplementation, voice therapy and complex genital reconstruction surgery with optional additional plastic surgeries. ${ }^{9}$

The last aspect of the transition process, which creates plenty of problems for transgender patients, is the change of their legal status. The formal change of gender is often perceived by patients as the final goal of the transition process.

\section{Status quo}

The current legal procedure of the legal change of gender assignment in Poland is problematic in a multifaceted way. The general problem arises from the lack of a specific legal act which would thoroughly regulate this matter. 
The present legal practice was created through case law, including mainly judicial activity of the Supreme Court of Poland. The judicial opinions on the legitimate procedure of the transition have been changing throughout the past years. The position expressed in various rulings of regional courts (sądy okręgowe, which have jurisdiction in such cases as the court of the first instance) on the subtleties of the proceedings on the change of legal sex differ significantly, which results from lack of specific legislation. These disparate opinions do not only create a lot of legal uncertainty, but are also inherently troublesome for transsexual individuals. It can be observed that many people seek legal advice in online communities for transsexuals. The question most commonly raised concerns before which particular court the legal sex change can be achieved most easily. ${ }^{10}$ The 3 main legal issues in this field concern the following: the legality of the surgical removal of genitals from the viewpoint of criminal law (and discussing its potential necessity to the process of transition), the procedure of birth certificate correction, and finally, the action from Article 189 of the Civil Procedure Code, ${ }^{11}$ which is now considered the legally appropriate way for transsexuals who want to change their legal gender.

\section{Legality of surgical intervention}

According to Article 156 of the Polish Penal Code, ${ }^{12}$ whoever deprives another person of the ability to procreate, shall be subject to imprisonment for a period of 1-10 years. Apart from hormonal therapy, the surgical operation of sex correction includes the removal of one's genitals to create organs resembling genitals of the other sex. In most cases, this entails depriving the individual of the ability to procreate, prima facie fulfilling the premises of the offence described in the aforementioned Penal Code provision. The Polish criminal law does not provide an explicit exception for this kind of medical treatment, unlike, for example, the Austrian Criminal Code. ${ }^{10}$ Despite the fact that not all transsexuals want to undergo this kind of treatment, this issue is still very important. The question of surgical treatment was discussed in Polish judicature as a potential prerequisite for a change of legal sex. It was perceived as a clear indicator that a person's feeling of being the opposite sex is permanent and irreversible, which was then considered as a requirement for a legal sex change.

Surgical treatment for MTF individuals consists primarily of genital surgery - vaginoplasty. ${ }^{13}$ The techniques vary, depending on the performing center. The most commonly performed type of treatment is the penile inversion procedure, which includes orchiectomy, penile deconstruction with the creation of a sensitive neoclitoris and the creation of the vaginal cavity. ${ }^{13}$ The procedure is irreversible, but only a small proportion of patients express regret or are not satisfied with their new organ's functionality. ${ }^{14}$ Some transgender women perform additional surgeries, which include breast augmentation, thyroid gland reduction and facial feminization surgery. Those additional surgeries can reduce gender dysphoria to some extent. ${ }^{15-17}$

Surgical treatment in FTM may be considered as a twostep procedure. The first, most common procedure is breast reduction (bilateral mastectomy). ${ }^{18}$ Naturally, it does not lead to the loss of reproductive capabilities of the individual. Most patients are satisfied with the procedure, as breasts are considered to be one of the most significant symbols of femininity. The next, more serious steps include an oophorectomy, hysterectomy and vaginectomy, followed by penile reconstruction surgery. ${ }^{19}$ Those procedures are more invasive and lead to the definitive loss of reproductive ability. In addition to decreasing gender dysphoria, they may also be considered as gynecological cancers prophylaxis. Penile reconstruction surgery is performed by only a few centers and, in addition to being expensive, is associated with frequent unsatisfactory esthetic and functional results. ${ }^{20}$

The legality of sex reassignment surgery was a subject of discussion in Polish criminal law doctrine. This issue is important, because if sex reassignment surgery is to even be considered a potential prerequisite for a legal sex change, it should be legal from the viewpoint of criminal law. As noted by Rejman, criminal responsibility is "autonomous" from other branches of law, i.e., administrative or civil law cannot justify criminally illegal acts. ${ }^{21}$

The most popular way of justifying sex change surgery is to classify it as a medical intervention. It is important to note that views on the legality of medical interventions in criminal law are also divided in Polish criminal law doctrine. While some authors classify them as initially legal, others treat them as a case of criminal law justification. The main controversy behind sex reassignment surgery in Polish criminal legal doctrine concerns the medical character of the aim of the treatment.

The first ruling, which discussed the medical character of sex reassignment surgery, was the decision of the Voivodeship Court for the Capital City of Warsaw, arguing that if the plaintiff's psyche was in danger of permanent and irreversible damage, and he feels like a woman, then there are no contraindications against sex reassignment surgery from the viewpoint of medical ethics. ${ }^{22}$ The medical character of the treatment was then reaffirmed by the Supreme Court in $1978 .{ }^{23}$ Other decisions made by the Supreme Court in cases regarding transsexualism did not mention the matter of the medical character of the surgery nor the criminal aspects, although one may argue that they were deemed legal implicitly. ${ }^{24}$

However, the opinions of Polish criminal law experts' are divided with regard to both the question of acceptability of sex reassignment surgery and its medical character. Some authors deny its medical character, seeing them as legal nonetheless. The first group of authors, including 
notably Rejman and Filar, argue against seeing the surgery as medical intervention (due to the questionable medical character of the surgery). ${ }^{21,25}$ This claim is often based on the premise that surgery is only symptomatic treatment and, therefore, cannot heal the patient. According to Rejman, constructed organs are "dummies", unable to perform their biological function. ${ }^{21}$ Filar notes that the surgery does not bring back the "correct" gender identification; instead, it exacerbates the pathological state. ${ }^{26}$ Other authors denying the medical character of the sex reassignment surgery include Rozental, Gromadzki, Safjan, and others. ${ }^{27-29}$ Another idea is to justify this kind of treatment through the institution of necessity; however, the main problem with this line of reasoning seems to be the lack of required immediacy of danger. Other authors propose treating it as an instance of specific extralegal justification. ${ }^{9}$

The aforementioned argumentation lies on the very narrow definition of health. As noted by Przybylska, the definition of 'health' is established in the Constitution of the World Health Organization ("Health is a state of complete physical, mental and social well-being and not merely the absence of disease or infirmity.") and includes the state of mental and social well-being. ${ }^{30}$ Even if sex reassignment surgery is considerd as symptomatic treatment, it definitely heads towards improving the mental and social well-being of a patient. It is worth mentioning at this point the high prevalence of depression and incidence of suicides among the transgender population. Studies indicate that up to $22-43 \%$ of the transgender population report a history of suicide attempts. ${ }^{31}$ Some authors state that sex reassignment surgery, along with the transition process, has a positive and protective impact on mental health and reduces the risk of suicide. ${ }^{31}$ The essence of transsexualism could be described as follows: both the mind and the body are healthy on their own, but the essence of the disorder lies in the extreme disparity between them. There is no way of changing the mind (which may be a result of developing a selected sexual identity in the brain), so the only way to deal with this discrepancy is through adaptive treatment. The group of authors who stress the medical character of the treatment includes Daniluk, Leszczyński and Sakowicz. ${ }^{32}$ Interestingly enough, the Supreme Court of Poland has generally considered surgery as a prerequisite for legal sex change. In one of its rulings, it stated that legal sex change can be carried out before the surgical sex correction if "the attributes of a newly formed gender are prevailing and that state is irreversible". ${ }^{33}$ Also, in a verdict from 1991, the Supreme Court suggested that surgical correction is generally a prerequisite for filing a claim for a legal sex change, because it shows that the sexual identity has a permanent character. ${ }^{34}$ The opinion that undergoing a sex reassignment surgery is (de lege lata) or should be (de lege ferenda) a precondition for legal sex change used to be prevalent in the Polish legal doctrine. ${ }^{25,27,35-37}$ However, in the newer literature, a number of authors disagree with this statement. ${ }^{10,38-40}$

There are 2 main arguments supporting the claim that sex reassignment surgery should be required for a legal sex change: the argument based on certainty and the argument based on 'social order' (meaning practical consequences, especially those related to family law). The first argument is based on the fact that surgery can be understood as sufficient evidence confirming that one's gender dysphoria is of permanent and irreversible character. Even if we accept that assertion, sufficient does not mean necessary. There are transsexuals who do not want to, or even cannot, as a result of the medical contraindications, undergo this kind of therapy. The reasons may be various (lack of funds is just one). What is more, transsexualism, as a medical category, is a matter of fact, so the opinion of an adequately qualified expert or experts should be proper evidence for the courts in this matter. ${ }^{39}$

The second argument is more multilayered and problematic. There are potential situations in which a person that changed their sex legally, but still has biological organs of the former, may enter a legally troublesome placement. Most of these include family law cases: a marriage of 2 "externally" same sexes, or the conception of a child that would have 2 mothers. Each of these situations, however, requires a separate discussion. ${ }^{41}$

The consequences of adopting a different solution, i.e., the necessity of undergoing surgical therapy before the legal change of sex, are far graver. It would prima facie mean forcing individuals to sterilize themselves. This raises serious concerns from the viewpoint of human rights. This kind of regulation could be classified as incompatible with the constitutional principle of human dignity.$^{10,40}$ In the context of international law, such a requirement would explicitly violate Yogyakarta Principles, which is an influential soft law declaration on human rights. Moreover, in recent rulings, Y.Y. v. Turkey, and A.P., Garçon and Nicot v. France, the European Court of $\mathrm{Hu}-$ man Rights declared that the requirement of sterilizing treatment is an infringement of the right to private life, guaranteed in the article 8 of the European Convention on Human Rights. ${ }^{42,43}$

Lack of agreement in Polish legal doctrine concerning the legality of surgical sex correction and the popularity of the thesis that it is a necessary prerequisite for a legal sex change in court proceedings lead to a vicious circle. Physicians may be afraid to perform such a surgery because of criminal responsibility, and courts may require it, nonetheless, as the basis for the ruling. ${ }^{39}$ This situation may be especially troublesome for transsexuals, potentially even preventing them from changing their legal sex in Poland or from undertaking medical treatment. Not surprisingly, this may lead to "sex change tourism", not only international, but also of a domestic kind. ${ }^{10}$ 


\section{Sex assignment and correction of birth certificate}

To understand the notion of sex in Polish law, one should start with the procedure of sex assignment. It starts immediately after a child is born. The healthcare facility in which the child is born is obliged to issue a birth card, which includes, i.a., an entry with an alternative: male or female. ${ }^{44}$ The Civil Registry Records Act, which regulates this issue, does not provide any term, but it can be inferred from a general rule established in the Administrative Proceedings Code. ${ }^{45,46}$ The birth certificate should be, therefore, issued without undue delay, utmost within 7 days of birth, and then the healthcare facility is obliged to deliver it within 3 days to the Civil Registry Office. Parents are also obliged to notify the Civil Registry Office within 21 days of the issuance of the birth certificate. The protocol of notification also includes an entry for sex. Finally, Civil Registry Office shall issue the birth certificate in the date of notification on the basis of birth card and parents' notification protocol. The birth certificate serves as the main legal measure of identifying a child, and is needed in an extensive number of procedures.

The development of transgenderism during a lifetime - from birth to adulthood - is a controversial issue. There is a particularly discussed issue of transgender adolescents who present gender dysphoria similarly to adults, however, before reaching full adolescence. This situation creates an opportunity to start hormonal treatment before the full development of tertiary sexual characteristics. This leads to much better technical treatment results, as the tertiary features of the unwanted sex have not yet developed. However, treatment of transgender youth leads to a potential trap - gender dysphoria in youth does not have to persist into adulthood. The study of Wallien and Cohen-Kettenis showed that gender dysphoria presentment in the pre-pubertal population exists in adulthood only in the minority of subjects. ${ }^{47}$ This is why medical treatment before adolescence is generally not recommended; however, The World Professional Association for Transgender Health (WPATH) suggests hormonal suppression of puberty by gonadotropin-releasing hormone $(\mathrm{GnRH})$ analogues in up to Tanner stage II-IV, which allows transgender individuals to temporarily postpone puberty. ${ }^{48}$ From the bioethical point of view, such course of action still remains controversial, as GnRH analogues are not free from side effects. Therefore, the legal aspects of the problem are even more complicated.

It may seem that correction of birth certificate could be a valid way for legal sex change in Poland. However, at the moment, the Supreme Court ruled out this way of proceeding and pointed out that article 189 of the Civil Proceedings Code (hereinafter referred to as CPC) stipulates the valid way to proceed. ${ }^{11,34,49}$ Nonetheless, the procedure of correcting a birth certificate should be evaluated here as well (since it was legally valid until 1989, and there are important arguments for opting for this procedure). According to article 36 of Civil Registry Record Act, rectification of a civil registry record of this kind shall be performed by the court in non-litigious proceedings. The first case regarding changing the legal sex in Poland was in 1964 and concerned a MTF transsexual who had already undergone surgical correction and filed for the sex marker to be changed on her birth certificate. ${ }^{45,50}$ The Voivodeship Court for the Capital City of Warsaw, acting as the court of second instance (the first instance court had dismissed the claim), admitted that such a possibility exists. To determine the sex of a claimant, the Court ascertained that claimant's psyche has primacy, and the decision could not be based solely on the anatomical criterion. ${ }^{10}$ The Court also addressed the legal issue of admissibility of the correction of the birth certificate: on the basis of the law applicable at the time, the correction was admissible only if the certificate was initially drawn up recklessly or erroneously. The correction was effective ex tunc. According to the opinion of the Court, the act was drawn up correctly at the outset, since the circumstances justifying its invalidity occurred later - at the moment of the change of sex by the claimant. Therefore, the provisions regarding the correction of the birth certificate were not applied by the Court directly but only by analogy. As noted by Ostojska, this argument contains an inconsistency: if the Court acknowledged the priority of the mental state as crucial for determining the sex, why was the change recognised as the moment of surgical treatment? ${ }^{10}$ The process of correcting the birth certificate per analogiam was then confirmed by the Supreme Court in $1978,{ }^{23}$ although it regarded the case of an intersexual person. The Supreme Court stated that, as an exception, a birth certificate can be corrected if the claimant has not yet undergone the surgical correction, once again underlining the importance of the psychological aspect of sex. In addition, the possibility of a legal change of sex was linked to the irreversibility and finality of the factual change of sex, but the latter was not defined, apart from explicit exclusion of the surgical correction criterion. ${ }^{10}$ This line of reasoning was approved from the viewpoint of psychiatry and sexology, but was criticised on the legal grounds. ${ }^{10}$ Legal doctrine indicates that a civil registry act cannot be corrected if it was drawn up correctly, even by analogy, because that would mean that it is henceforth effective. ${ }^{25,37}$ Since it is assumed that transsexualism proceeds throughout one's life, the birth certificate only becomes incorrect and that cannot be the premise to correct it in this way. Even if, as it was pointed out above, we assume that transsexualism is innate, one can argue that we have no valid way to diagnose it at birth, so from a practical point of view the certificate could not be classified as made erroneously. A similar argument was proposed by Ignatowicz. There were extremely rare cases in which an expert opinion stating that transsexualism was innate convinced courts to correct birth certificates, even when this way of proceeding was already generally 
proscribed by the ruling of the Supreme Court, as described below. ${ }^{51}$ The Supreme Court ascertained in 1989 that the occurrence of transsexualism shall not be a basis for correction of the sex entry in a birth certificate and, moreover, that there was no legal basis at the time for any kind of judicial sex change. ${ }^{49}$ Zielonacki instead proposed the general declaratory action from the article 189 of CPC as the legitimate way to proceed. ${ }^{37}$ The Supreme Court then affirmed this line of reasoning in 1991, reopening a way for transsexuals to change their legal sex. ${ }^{34}$

\section{Action from Article 189 of Civil Procedure Code}

According to Article 189 of CPC, a plaintiff may demand a judicial ascertainment of the existence or nonexistence of a legal relationship or a right if they have legal interest in it. This rule describes a general action and applies to all cases not specified elsewhere (such as, e.g., ascertainment of the nonexistence of marriage). However, as an action in litigious proceedings, it always requires naming a defendant (which is quite problematic, as it will be shown below). A ruling has a declaratory character. According to Zielonacki, gender identity should be classified as a personal right and could be protected by an action to ascertain the correct sex. ${ }^{37}$ This view was confirmed by the Supreme Court in 1991, which established the action from Article 189 of CPC as a proper legal solution for the change of sex. ${ }^{34}$ This ruling is a result of such proceedings and is effective ex nunc. It is not a basis for the correction of birth certificate, but it suggests that an "additional annotation" should be included, which is an institution from the Civil Registry Record Act - Article 21 of the Act of 1986 (binding at the time), Article 24 of the now binding Act of 2014. ${ }^{45}$ What is interesting, the Supreme Court stated that the persistent feeling of belonging to the other sex is a personal right, which is the legal basis for the change of sex; however, generally, this feeling of belonging can be proven only by surgical correction. This raised the question of whether the personal right under protection is the personal feeling of belonging to a sex, or rather the sex per se. ${ }^{10}$ As noted by Safjan, the result of the proceedings is the ascertainment of sex as such, and not the personal feeling. ${ }^{35}$ In a following ruling in 1995, the Supreme Court did not mention the premise of protection of a personal right and addressed the question of passive legal standing (i.e., who should be sued) in these type of cases. ${ }^{52}$ The Court determined that plaintiff's parents are the persons to be sued (or the guardian ad litem, appointed by court, in the case of parents - or one of them - being deceased), denying other propositions posed in the literature, such as the director of the registry office (because they are not related to the plaintiff on the ground of family law). It should be noted, however, that in a few legal systems suing the registrar is the legally binding solution, for example in Hong
Kong (see Wv. Registrar of Marriages (2013). HKCFA 39). ${ }^{53}$ Passive legal standing was then reviewed by another ruling of the Supreme Court in 2013 which highlighted the shortcomings of parents as passively legitimized, and indicated that the plaintiff's spouse and children should have passive legal standing in the first place. ${ }^{54}$ This solution is currently legally binding.

The Supreme Court indicated the vital reasons against assigning parents passive legal standing. Firstly, passive legal standing in declaratory action from the article 189 of CPC is not chosen arbitrarily, but rather should concern persons that are legally interested in the result of the proceedings. The sex of a child, however, does not affect the legal relationship between parents and the child. Moreover, parents cannot discriminate their children on the basis of sex. If they support their child, then a contradictory action against them is paradoxical and incompatible with the general legal standards of civil proceedings. If they do not accept their child's transsexuality, a court ruling, apart from having no legal impact on their family status, would probably not change their minds whatsoever. Instead, the Supreme Court proposes subjects to whom the plaintiff's sex may be legally relevant. Sex is legally relevant, i.a., in the case of marriage and parenthood. Therefore, passive legal standing in those cases should be ascribed firstly to the spouse and children, since the plaintiff fulfilled their legal and social role as a wife/ husband and mother/father. The argument of the Supreme Court goes in the right direction, but it does not concern situations in which the plaintiff is celibate and childless. These cases are the most common. ${ }^{10}$ It seems that the source of the problem is the factual, psychophysical state of the plaintiff, not the socio-legal relations of family law. Therefore, non-litigious proceedings that do not require suing any other person seem to be more suitable for this type of case. However, as noted by the Supreme Court, sex has an important role in family law, especially in the case of marriage. On the other hand, it can be argued that divorce as a necessary requirement before the change of legal sex may be a reasonable solution in the case of married plaintiffs, since it avoids the problem of same-sex marriages which are prohibited in the Polish legal system. This kind of prerequisite has been accepted by the European Court of Human Rights in Parry v. the United Kingdom, $R$. and F. v. the United Kingdom, and Hämäläinen v Finland, and is in fact often used by Polish courts. ${ }^{10,55,56}$

\section{An utmost need for regulation}

In the light of the aforementioned issues, it is clear that status of transsexual people in Poland is particularly problematic, especially if they want to change their legal sex. There are no undisputable legal grounds for justifying the surgical treatment, and, what is even more important, the 2 legally plausible civil procedures of sex change do 
not provide a proper solution, since they are vitiated with shortcomings that have both a medico-legal and social character. The outdated birth certificate correction procedure may have problematic implications in family law, as it was effective ex tunc. The now-binding procedure through the general declaratory action from 189 CPC requires naming defendants, which is not only questionable from the viewpoint of the principles of civil proceedings, but may provide additional distress for plaintiffs. This situation results in legal uncertainty and may be even seen as violating the human rights of transsexual people, which are, first and foremost, guaranteed in the Constitution of Poland. ${ }^{40} \mathrm{New}$ legislation which would aim to regulate the issues mentioned above may provide a comprehensive solution to most problems, as well as providing additional positive impact on the situation of transsexuals. This may be a vital point for mental health of transsexual people. Unlike some opinions presented in the Polish doctrine in this context, the law could and should have a therapeutic role to some extent. ${ }^{25}$ As noted by the proponents of therapeutic jurisprudence, the practice of law (understood generally as legal procedures and activities of judges, lawyers, etc.) may have serious consequences for the well-being of people who are participants of legal proceedings. ${ }^{57}$ This issue is especially important with regard to mental healthcare. Traditionally, therapeutic jurisprudence scholars focused on the issues related mostly to institutionalization and direct influence of legal decision-makers, but it seems that the scope of the therapeutic aspect of law applies to the discussed matter. Designing an adequate procedure for changing the legal sex and regulation of other legally relevant aspects of transsexualism may be helpful in removing the negative stereotypes about transsexualism in the Polish society. It is often pointed out that the act of changing the legal sex is very important in the therapy.

The lack of a specific statutory regulation on the legal sex change procedure for transsexuals may be somehow surprising in the light of the fact Poland was the first country in Europe to have an openly transsexual member of parliament, Anna Grodzka. In 2013, she was representing a group of members of Sejm (lower chamber of Polish parliament) that submitted a bill for gender recognition, which was eventually adopted by the parliament after revisions. ${ }^{58}$ However, in 2015, newly elected President Andrzej Duda vetoed the bill and redirected the act to the Parliament. The bill was then discontinued with the end of the term of the Parliament and new election. At the time of writing of this article in February 2019, absolutely no relevant legislative action had been undertaken by the next Parliament.

The bill aimed to solve many of the aforementioned problems. ${ }^{59}$ It introduced, i.a., a non-litigious type of proceedings which would not require suing the parents. Moreover, it required the cases to be heard in camera (i.e., non-publicly), and regulated some implications of the sex change for family law and social security. However, the process of medical assessment of transsexualism required in the bill was not flawless; for instance, it did not meet the requirements of WHO. The only reference to medical authorities was the need of providing 2 independent opinions of physicians or of a physician and a certified clinical sexologist, which would confirm the the gender identity is different from the birth-assigned sex. There was not a single word about the clinical criteria needed to be met during the diagnostic process.

Apart from the medico-legal problems, a number of issues connected with transgenderism depend on sociopolitical views. ${ }^{59}$ Social issues related to transsexuality seem to be mostly advocated by the LGBT communities and organizations, mostly left-wing-oriented. At the time of the birth of LGBT movement, all of the conditions included in the name - lesbians, gays, bisexuals, and transsexuals - were considered to be diseases and medical conditions. As the medical knowledge progressed along with cultural changes, the first 3 "letters" lost their previous status and became as normal as heterosexuality in Western societies. The continuous fight against discrimination and for equal rights for those individuals is nevertheless still present and is one of the fundamental issues of left-wing political groups. However, if we understand the last "letter" strictly as transsexualism (as defined above), it remains primarily a medical problem, and not only a cultural one. Since Poland is generally a conservative society, there may be little chance of changing and improving the current law for the sake of transsexuals in Poland in the foreseeable future as long as it is advocated only by the left-wing organizations. In addition, knowledge about transsexuality in the Polish society seems to be poor. ${ }^{60}$ The co-authors of this article, who are clinical professionals, have personal experience indicating that a crushing majority of medical students have almost no knowledge about the issue. In our personal opinion, the 2 measures that should be taken in order to help the process are as follows: firstly, the transsexual issue should not be advocated solely by the organizations associated with the left-wing political environment, but also by the medical community (e.g., Polish Society of Sexology or Polish Society of Sexual Medicine). Secondly, any serious social awareness campaign could provide vital support. However, it seems to be crucial that this campaign should concentrate on the medical nature of the problem and the troublesome legal issues related to it.

\section{Conclusions}

The legal issues related to transsexualism in Poland generate many problems which have direct negative sociomedical consequences. The main source of these problems is the lack of a particular statutory regulations on the procedure of the change of sex, as well as on the legal basis for surgical intervention. The absence of such regulations is striking, especially since a new statutory act is a common postulate formulated in the legal literature. The most 
notable drawback of the currently binding judicial procedure regarding legal sex change is the requirement of suing parents, spouse and children. This could be avoided if the change was performed in a non-litigious mode of proceedings, in which the medical criteria by the WHO and an opinion of a strictly regulated team of experts were central factors.

\section{ORCID iDs}

Paweł Bartnik (1) https://orcid.org/0000-0002-9873-8833

Joanna Kacperczyk-Bartnik (1) https://orcid.org/0000-0003-2539-3894 Maciej Próchnicki (1) https://orcid.org/0000-0002-2151-9915

Agnieszka Dobrowolska-Redo (1) https://orcid.org/0000-0002-8111-0476 Ewa Romejko-Wolniewicz (1) https://orcid.org/0000-0003-1732-9577

\section{References}

1. World Health Organization. The ICD-10 classification of mental and behavioural disorders: Clinical descriptions and diagnostic guidelines. Geneva, Switzerland: World Health Organization; 1992.

2. Saraswat A, Weinand JD, Safer JD. Evidence supporting the biologic nature of gender identity. Endocr Pract. 2015;21(2):199-204.

3. Ahmadzad-AsI M, Jalali AH, Alavi K, et al. The epidemiology of transsexualism in Iran. J Gay Lesbian Mental Health. 2010;15(1):83-93.

4. Collin L, Reisner SL, Tangpricha V, Goodman M. Prevalence of transgender depends on the "case" definition: A systematic review. J Sex Med. 2016;13(4):613-626.

5. Stefánsson JG, Líndal E, Björnsson JK, Guômundsdóttir Á. Period prevalence rates of specific mental disorders in an Icelandic cohort. Soc Psychiatry Psychiatr Epidemiol. 1994;29(3):119-125.

6. World Health Organization. International Classification of Diseases $11^{\text {th }}$ Revision. The global standard for diagnostic health information. https://icd.who.int/. Accessed February 21, 2019.

7. American Psychiatric Association. Diagnostic and statistical manual of mental disorders. $5^{\text {th }}$ ed. Arlington, VA: American Psychiatric Publishing; 2013.

8. Owen-Smith AA, Sineath C, Sanchez T, et al. Perception of community tolerance and prevalence of depression among transgender persons. J Gay Lesbian Mental Health. 2017;21(1):64-76.

9. Coleman E, Bockting W, Botzer M, et al. Standards of care for the health of transsexual, transgender, and gender-nonconforming people, version 7. Int J Transgend. 2012;13(4):165-232.

10. Ostojska J. Sadowa zmiana płci [doctoral dissertation]. University of Warsaw, Poland; 2014

11. Ustawa z dnia 17 listopada 1964 r. - Kodeks postępowania cywilnego [Civil Procedure Code] DzU 2018.155 (uniform text).

12. Ustawa z dnia 6 czerwca 1997 r. - Kodeks karny [Penal Code] DzU 2017.2204 (uniform text).

13. Horbach SE, Bouman MB, Smit JM, Özer M, Buncamper ME, Mullender MG. Outcome of vaginoplasty in male-to-female transgenders: A systematic review of surgical techniques. J Sex Med. 2015;12(6): 1499-1512.

14. Lawrence AA. Patient-reported complications and functional outcomes of male-to-female sex reassignment surgery. Arch Sex Behav. 2006;35(6):717-727.

15. Kanhai RC, Hage JJ, Asscheman H, Mulder JW. Augmentation mammaplasty in male-to-female transsexuals. Plast Reconstr Surg. 1999; 104(2):542-549.

16. Morrison SD, Vyas KS, Motakef S, et al. Facial feminization: Systematic review of the literature. Plast Reconstr Surg. 2016;137(6):1759-1770.

17. Wolfort FG, Dejerine ES, Ramos DJ, Parry RG. Chondrolaryngoplasty for appearance. Plast Reconstr Surg. 1990;86(3):464-469.

18. Namba $Y$, Watanabe T, Kimata Y. Mastectomy in female-to-male transsexuals. Acta Med Okayama. 2009;63(5):243-247.

19. Monstrey SJ, Ceulemans P, Hoebeke P. Sex reassignment surgery in the female-to-male transsexual. Semin Plast Surg. 2011;25(3):229-244.

20. Klein C, Gorzalka BB. Sexual functioning in transsexuals following hormone therapy and genital surgery: A review. J Sexual Med. 2009; 6(11):2922-2939.
21. Rejman G. Glosa do uchwały SN z dnia 22 czerwca 1989 r., III CZP $37 / 89$. Orzecznictwo Sąów Polskich i Komisji Arbitrażowych. 1991;2:35.

22. Kubiak R. Karnoprawna dopuszczalność zabiegów adaptacyjnych - stan obecny i proponowane regulacje. Acta Universitatis Lodziensis. Folia luridica. 2015;74:83-104.

23. Sąd Najwyższy [Supreme Court of Poland]. Uchwała Sądu Najwyższego z dnia 25.02.1978 r., III CZP 100/77. Orzecznictwo Sądów Polskich i Komisji Arbitrażowych. 1983;10:217.

24. Sąd Najwyższy [Supreme Court of Poland]. Uchwała Sądu Najwyższego z dnia 08.05.1992 r., III CZP 40/92. Prawo i Życie. 1992;34:15

25. Filar M. Prawne i społeczne aspekty transseksualizmu. Państwo i Prawo. 1987;7:67-77.

26. Filar M. Dwie płci w jednym ciele. Prawo i Życie. 1987;19:4-5.

27. Rozental K. O zmianie płci metrykalnej de lege ferenda. Państwo i Prawo. 1991;10:64-73.

28. Gromadzki C. Poczucie przynależności do danej płci jako kryterium przy zmianie oznaczenia płci w akcie urodzenia transseksualistów. Przegląd Sąowy. 1997;10:83-86.

29. Safjan M. Prawo i medycyna. Ochrona praw jednostki a dylematy współczesnej medycyny. Warszawa, Poland: Oficyna Naukowa; 1998.

30. Przybylska J. Cywilnoprawne aspekty instytucji zgody pacjenta na interwencję medyczną i jej definicja, Monitor Prawniczy. 2003;16: 740-744.

31. Bauer GR, Scheim Al, Pyne J, Travers R, Hammond R. Intervenable factors associated with suicide risk in transgender persons: A respondent driven sampling study in Ontario, Canada. BMC Public Health. 2015;15:525.

32. Daniluk P. Zabieg „chirurgicznej zmiany płci” u transseksualistów jako czynność lecznicza. Prawo i Medycyna. 2007;1(26):99-113.

33. Sąd Najwyższy [Supreme Court of Poland]. Uchwała Sądu Najwyższego z dnia 25.02.1978 r., III CZP 100/77. Orzecznictwo Sądów Polskich i Komisji Arbitrażowych. 1983;10:217.

34. Sąd Najwyższy [Supreme Court of Poland]. Postanowienie Sądu Najwyższego z dnia 22.03.1991 r., III CRN 28/91. Przegląd Sądowy. 1991; 5-6:118-122.

35. Safjan M. Glosa do postanowienia z dnia 22 marca 1991 r. (III CRN 28/91). Przeglad Sadowy. 1991;2:78-90.

36. Daniluk P. Prawne aspekty "chirurgicznej zmiany płci" u transseksualistów (uwagi de lege ferenda). Państwo i Prawo. 2007;5:71-84.

37. Zielonacki A.Zmiana płci w świetle prawa polskiego. Ruch Prawniczy, Ekonomiczny i Socjologiczny. 1988;2:39-55.

38. Szeroczyńska M, Śledzińska-Simon A. Założenia zmian prawnych dotyczących osób transpłciowych w prawie polskim. In: Dynarski W, Śmiszek K, eds. Sytuacja prawna osób transpłciowych w Polsce-raport z badań i propozycje zmian. Warszawa, Poland: Trans-Fuzja; 2013.

39. Michalik J. Kiedy ciało jest więzieniem, a państwo strażnikiem. Analiza procedury zmiany płci metrykalnej w Polsce ze szczególnym uwzględnieniem kryterium ustalenia płci. Internetowy Przegląd Prawniczy TBSP UJ. 2012;2:61-86.

40. Karakulski J, Pyłko J. Wątpliwości konstytucyjne w zakresie sądowej procedury zmiany płci. Internetowy Przeglad Prawniczy TBSP UJ. 2017; 2:65-81.

41. Dunne P. Transgender sterilisation requirements in Europe. Med Law Rev. 2017;25(4):554-581.

42. Y.Y. v. Turkey (2015). 14793/08.

43. A.P., Garçon and Nicot v. France (2017). 79885/12, 52471/13.

44. Rozporządzenie Ministra Zdrowia z dnia 07.12.2017 r. w sprawie wzorów karty urodzenia i karty martwego urodzenia [Ordinance of the Minister of Health on the formats of the birth cards and the stillbirth cards]. DzU 2017.2305.

45. Ustawa z 28.11.2014 r. - Prawo o aktach stanu cywilnego [Civil Registry Records Act]. DzU 2016.2064 (uniform text).

46. Ustawa z 14.06.1960 r. - Kodeks postępowania administracyjnego [Code of Administrative Procedure]. DzU 2017.1257 (uniform text).

47. Wallien MS, Cohen-Kettenis PT. Psychosexual outcome of genderdysphoric children. J Am Acad Child Adolesc Psychiatry. 2008;47(12): 1413-1423.

48. World Professional Association for Transgender Health (WPATH). WPATH Standards of Care for the Health of Transsexual, Transgender, and Gender Nonconforming People, $7^{\text {th }}$ Version. 2011. https://www. wpath.org/publications/soc. Accessed July 31, 2018. 
49. Sąd Najwyższy [Supreme Court of Poland]. Uchwała Sądu Najwyższego 7 sędziów - zasada prawna z dnia 22.06.1989 r., III CZP 37/89. Orzecznictwo Sadów Polskich i Komisji Arbitrażowych. 1991:2:35.

50. Sąd Wojewódzki dla m.st. Warszawy [Voivodeship Court for the Capital City of Warsaw]. Orzeczenie Sądu Wojewódzkiego dla m.st. Warszawy z dnia 24.09.1964 r., II Cr 515/64. Państwo i Prawo. 1965;10:600-601.

51. Ignatowicz J. Glosa do uchwały Sądu Najwyższego III CZP 118/95. Orzecznictwo Sąów Polskich. 1996;4:78.

52. Sąd Najwyższy [Supreme Court of Poland]. Uchwała Sądu Najwyższego z dnia 22.09.1995 r., III CZP 118/95. Orzecznictwo Sądu Najwyższego Izby Cywilnej, 1996;1:7.

53. Wv. Registrar of Marriages (2013). HKCFA.

54. Sąd Najwyższy [Supreme Court of Poland]. Wyrok Sądu Najwyższego z dnia 06.12.2013 r., I CSK 146/13. Orzecznictwo Sądu Najwyższego. Izba Cywilna. Zeszyt Dodatkowy. 2015;2:19.
55. Parry v. UK (2006). ECHR 42971/05.

56. R. and F. v. UK (2006). ECHR 35748/05

57. Wexler D. The development of therapeutic jurisprudence: From theory to practice. Revista Juridica Universidad de Puerto Rico. 1999;68: 691-705.

58. Sejm VII kadencji. Druk nr 1469. 2013. http://www.sejm.gov.pl/sejm7. nsf/PrzebiegProc.xsp?nr=1469. Accessed July 31, 2018

59. Brzozowski W. W sprawie projektu ustawy o uzgodnieniu płci. Przegląd Sejmowy. 2013;6(119):117-124.

60. Antoszewski B, Fijałkowska M, Kasielska A. Obraz transseksualistów typu kobieta-mężczyzna w społeczeństwie polskim. Psychiatr Pol. 2012;5:807-814. 